\title{
A comparison of methohexitone and thiopentone in electrocorticography
}

\author{
R. PAUL AND RUTH HARRIS \\ From the Department of Applied Electrophysiology, The National Hospital, Queen Square, London
}

The purpose of this paper is to draw particular attention to the use of methohexitone during electrocorticography (ECoG) in which activation, while recording from different derivations, may need to be repeated several times throughout the operation.

The value of methohexitone, known commercially as Brietal or Brevital, as a short-acting anaesthetic agent has been known for some while. Wyant and Chang (1959) and Dundee and Moore (1961) have stressed the very rapid recovery and absence of hangover effects after its use. Both groups of authors mention the abnormal muscle movements and hiccough often associated with the use of the drug. Riffin (1960), using a single channel widely-spaced bipolar EEG monitor while giving the drug, reported the appearance of 2 to $6 \mathrm{~Hz}$ waves of moderate voltage and a return to the pre-injection EEG pattern in $2 \frac{1}{2}$ to 5 minutes. Fibrillary movements of the face and lips were noted in several of his patients. He pointed out that methohexitone differed from earlier short-acting barbiturates in having no sulphur atom at the $\mathrm{C}_{2}$ position and a methyl group at the $\mathrm{N}_{1}$ position (Fig. 1).

Frank, Fraser, and Whitcher (1966) pointed out the value of intramuscular methohexitone in hyperactive or hyperirritable children. They thought the EEG patterns obtained resembled those seen with other sedatives. Fenton and Scotton (1967) noted quantitative differences between the narcosis induced by thiopentone and by methohexitone, the former giving more fast activity, the latter more slow activity. The basic EEG features, they considered, were the same and, although they said paroxysmal phenomena occurred equally commonly with the two drugs, they reported one patient in whom only methohexitone induced sharp wave or spike discharges. Goldie, Fried, Gould, and Pedersen (1968) described a method for using methohexitone intravenously in subnormal and severely disturbed children. They noted no specific changes attributable to the metho-

'Present address: The Maudsley Hospital, Denmark Hill, London S.E.5. hexitone, but again felt that the drug was especia留 valuable in these patients. Pampiglione (1965), liRe Riffin (1960), noted the short-lived effect and lack off persistent EEG changes. He remarked that the dru could be used repeatedly at intervals as short as 5 minutes during corticography and other procedures.

MATERIAL

The ECoG of 10 patients were studied. These were atl patients handicapped by severe epilepsy, which had faled to respond to drug therapy; one patient (case 3) तైas known before operation to have a tumour. The recordfngs
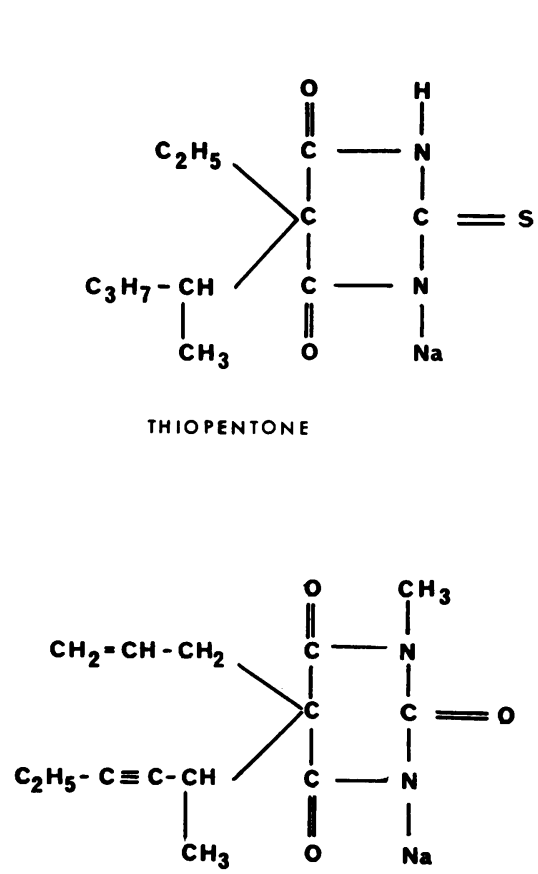

METHOHEXITONE

FIG. 1. The structural formulae of thiopentone methohexitone. 
were carried out in the operating theatre using a 16channel Mingograph apparatus. Various electrode placements were arranged on the cortex during each operation and depth electrodes were also inserted in a few patients. Bipolar and average reference recording was carried out for 5 minutes at least in each montage. All patients were given atropine or hyoscine premedication and anaesthetized with $\mathrm{N}_{2} \mathrm{O}, \mathrm{O}_{2}$, and either Halothane (cases 1 to 4) or Fluothane (cases 5 to 10 ).

During the course of the ECoG, intravenous injections of thiopentone were given to six patients and methohexitone to three; one patient was given both drugs. The amounts given were determined in co-operation with the anaesthetist and were sufficient to produce a considerable increase in the slow and fast rhythms in the ECoG. The records were subsequently reviewed in relation to the changes induced by thiopentone and methohexitone, particularly the appearance of fast activity and spikes and the rapidity with which they appeared after the injection.

\section{RESULTS}

A summary of the changes is given in the Table. Some clinical details are noted and, in addition, special points about pre-operative electroencephalograms, type of operation and pathological findings.

As will be noted, it was possible only in the first patient to make a direct comparison between the two drugs. In the other cases, where methohexitone was used, it was not felt clinically advisable at that

TABLE

DETAILS OF PATIENTS

\begin{tabular}{|c|c|c|c|c|c|c|}
\hline $\begin{array}{l}\text { Patient, } \\
\text { age, } \\
\text { sex }\end{array}$ & Type of attack & EEG location & Operation & Pathology & $\begin{array}{l}\text { Activating drug } \\
\text { (mg) }\end{array}$ & ECoG efficacy \\
\hline $1.38 \mathrm{M}$ & $\begin{array}{l}\text { GM complicated by } \\
\text { skull fractures }\end{array}$ & $\begin{array}{l}\text { Multifocal but left } \\
\text { temporal sharp waves } \\
\text { and some spikes } \\
\text { predominate }\end{array}$ & Biopsy & $\begin{array}{l}\text { Compatible with old } \\
\text { traumatic scar }\end{array}$ & $\begin{array}{l}\text { Thiopentone }(100) \\
\text { Methohexitone (100) }\end{array}$ & $\begin{array}{l}\text { Poor } \\
\text { Very good. See text } \\
\text { and Fig. } 2\end{array}$ \\
\hline $2.37 \mathrm{M}$ & GM and psychomotor & $\begin{array}{l}\text { Pre-op. EEG including } \\
\text { two sphenoidals with } \\
\text { methohexitone showed } \\
\text { right anterior temporal } \\
\text { spike focus laterally } \\
\text { and inferiorly }\end{array}$ & $\begin{array}{l}\text { Temporal } \\
\text { lobectomy }\end{array}$ & $\begin{array}{l}\text { Macroscopic and } \\
\text { microscopic-no } \\
\text { abnormality }\end{array}$ & Methohexitone (50) & Very effective. Fig. 3 \\
\hline $3.24 \mathrm{M}$ & TLE & $\begin{array}{l}\text { Right anterior } \\
\text { temporal spike focus }\end{array}$ & $\begin{array}{l}\text { Temporal } \\
\text { lobectomy }\end{array}$ & $\begin{array}{l}\text { Macroscopic-tumour } \\
\text { removed } \\
\text { Microscopic-Grade II } \\
\text { astrocytoma }\end{array}$ & $\begin{array}{l}\text { Methohexitone (20) } \\
\text { Methohexitone (20) } \\
\text { Methohexitone (40) }\end{array}$ & $\begin{array}{l}\text { Very effective in } \\
40 \mathrm{mg} \text { dose only }\end{array}$ \\
\hline $4.9 \frac{1}{2} \mathrm{~F}$ & Left focal motor & $\begin{array}{l}\text { Right temporal slow } \\
\text { waves with spikes but } \\
\text { also generalized } \\
\text { discharges }\end{array}$ & $\begin{array}{l}\text { Temporal } \\
\text { lobectomy }\end{array}$ & $\begin{array}{l}\text { Macroscopic-nil } \\
\text { Microscopic-slight } \\
\text { increase in astrocytes } \\
\text { in white matter }\end{array}$ & Methohexitone (30) & $\begin{array}{l}\text { Spiking within } 10 \\
\text { sec of end of } \\
\text { injection }\end{array}$ \\
\hline $5.30 \mathrm{M}$ & GM and TLE & $\begin{array}{l}\text { Right anterior } \\
\text { temporal slow waves }\end{array}$ & $\begin{array}{l}\text { Temporal } \\
\text { lobectomy }\end{array}$ & $\begin{array}{l}\text { Macroscopic uncus } \\
\text { very gliotic } \\
\text { Microscopic-sclerosis } \\
\text { of uncus }\end{array}$ & Thiopentone (50) & Poor \\
\hline $6.20 \mathrm{M}$ & TLE & $\begin{array}{l}\text { Right temporal slow } \\
\text { waves }\end{array}$ & $\begin{array}{l}\text { Temporal } \\
\text { lobectomy }\end{array}$ & $\begin{array}{l}\text { Macroscopic-tumour } \\
\text { deep in medial part of } \\
\text { temporal lobe } \\
\text { Microscopic- } \\
\text { angiomatous mal- } \\
\text { formation of cavernous } \\
\text { type }\end{array}$ & Thiopentone (75) & $\begin{array}{l}\text { No spikes but } \\
\text { reduced fast response } \\
\text { over tumour }\end{array}$ \\
\hline $7.23 \mathrm{~F}$ & GM and TLE & $\begin{array}{l}\text { Right posterior } \\
\text { temporal sharp wave } \\
\text { focus }\end{array}$ & Biopsy & $\begin{array}{l}\text { Moderate astrocytosis } \\
\text { of white matter }\end{array}$ & Thiopentone (100) & $\begin{array}{l}\text { Spikes from depth } \\
\text { electrode before } \\
\text { thiopentone. No } \\
\text { additional help }\end{array}$ \\
\hline $8.21 \mathrm{M}$ & GM and minor & $\begin{array}{l}\text { Right frontal sharp } \\
\text { wave focus }\end{array}$ & Biopsy & $\begin{array}{l}\text { Slight astrocyte } \\
\text { activity, otherwise } \\
\text { normal }\end{array}$ & Thiopentone (50) & No spike activity \\
\hline $9.24 \mathrm{M}$ & $\begin{array}{l}\text { GM and minor } \\
\text { following head injury }\end{array}$ & $\begin{array}{l}\text { Polyspike and wave } \\
\text { sometimes bilaterally } \\
\text { synchronous but } \\
\text { predominantly left } \\
\text { frontal }\end{array}$ & $\begin{array}{l}\text { Excision } \\
\text { of scar }\end{array}$ & $\begin{array}{l}\text { Macroscopic-left } \\
\text { frontal scarring } \\
\text { Microscopic-normal } \\
\text { cerebral cortex showing } \\
\text { glial scar }\end{array}$ & Thiopentone (50) & $\begin{array}{l}\text { Suppressed spike } \\
\text { activity which had } \\
\text { been in the resting } \\
\text { record }\end{array}$ \\
\hline $10.21 \mathrm{~F}$ & GM and TLE & $\begin{array}{l}\text { Right fronto-temporal } \\
\text { spike focus }\end{array}$ & Biopsy & $\begin{array}{l}\text { Slight increase in } \\
\text { astrocyte activity in } \\
\text { white matter }\end{array}$ & $\begin{array}{l}\text { Thiopentone }(50) \\
\text { Thiopentone }(100) \\
\text { Thiopentone }(100)\end{array}$ & No spikes induced \\
\hline
\end{tabular}

M: male. F : female. GM: grand mal. TLE: temporal lobe epilepsy. 
time to subject the patient to the extra risk of repeating the procedure with thiopentone. The remaining cases, where thiopentone was used, were chosen from older case studies, before methohexitone was being used in this department.

Patient 1 was formerly a university lecturer whose epilepsy was complicated by a series of severe head injuries resulting from the attacks. His increasing intellectual deterioration and the failure to control his epilepsy with drugs finally made him unemploy- able, and surgical exploration was considerecto imperative. A direct comparison between the action of thiopentone and methohexitone during the sames operation showed the particular value of the latte $\frac{\bar{c}}{6}$ drug, as illustrated in Fig. 2. It was felt that theo information the surgeon required in this patient was? more quickly and easily obtained by using methohexitone. The repeated use and efficacy of metho hexitone is illustrated in Fig. 3 (case 2).

This is in contrast with cases 5 to 10 , in which
E.Co.G.

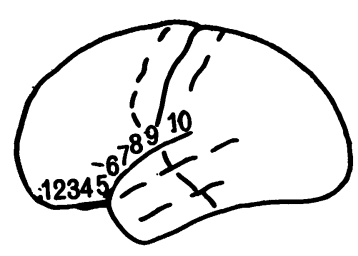

M.W. $37 y r$

$36677 / 13$

$21 \cdot 7 \cdot 67$

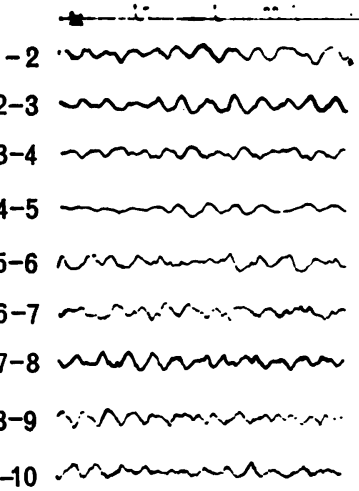

Resting record

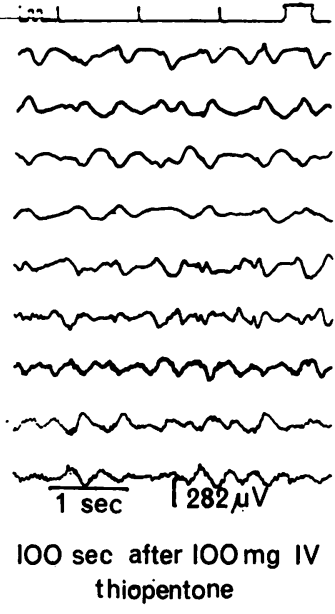

B
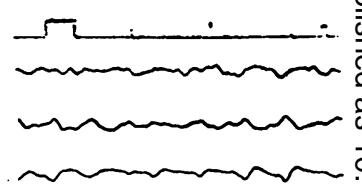

$\rightarrow$

A

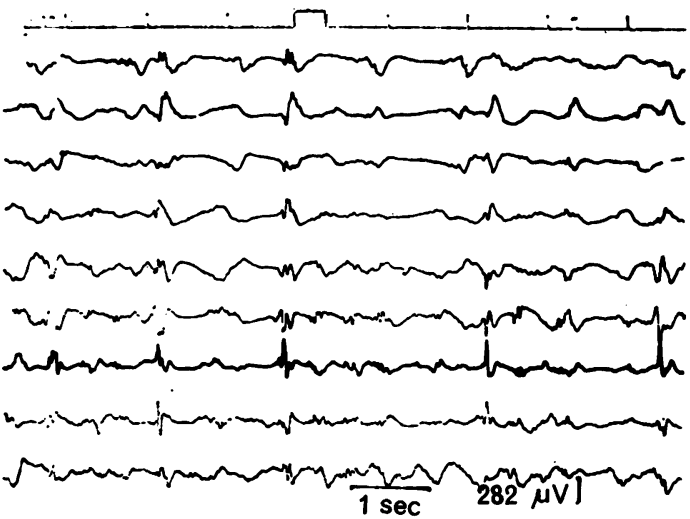

$100 \mathrm{sec}$ after $100 \mathrm{mg}$ IV methohexitone

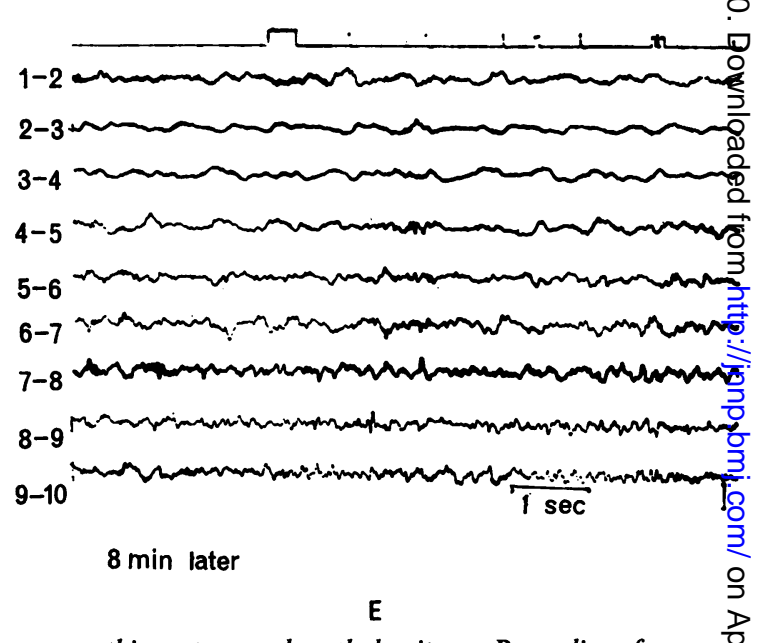

D

E

FIG. 2. Patient 1. Comparison of the effects of $100 \mathrm{mg}$ intravenous thiopentone and methohexitone. Recordings from an anteroposterior chain of electrodes. (A) Resting record showing slow wave activity but no definite spikes. (B and C) Recording after intravenous thiopentone. Ill-defined sharp waves can be seen about electrodes 6 and 7.(D) Clear spikes are ${ }^{\Omega}$ now seen, focal about electrode 7, facilitated by intravenous methohexitone. (E) Eight minutes later the effect of the 0 injection has largely disappeared. 
E.Co.G.
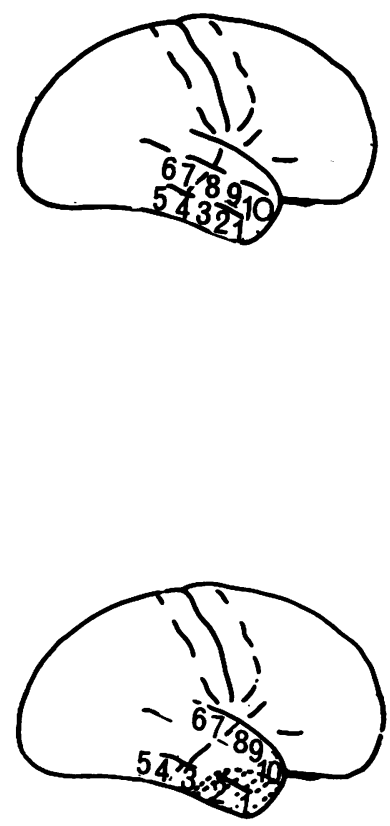

Area excised

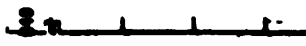

$1 \mathrm{sec}$

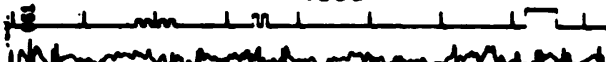

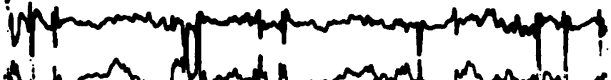
Nintoris

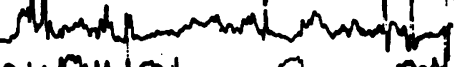

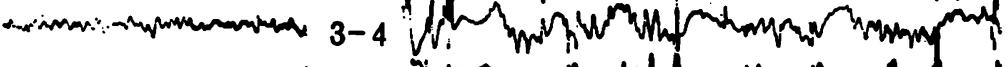

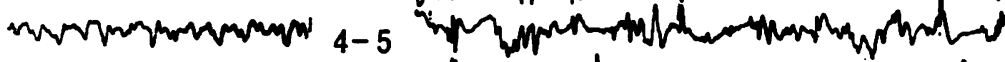

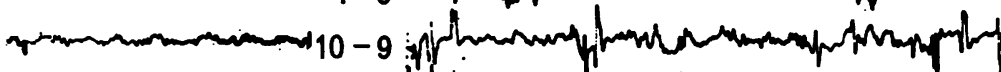

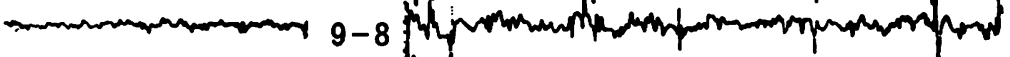

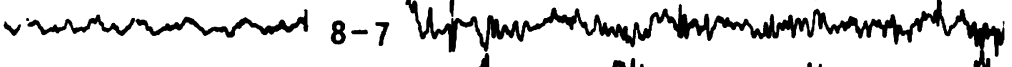

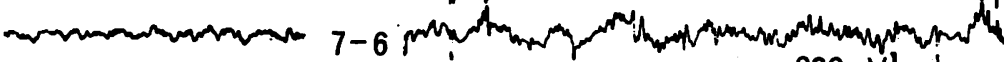
$282 \mu \mathrm{Vl}$

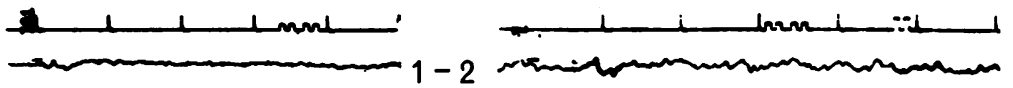

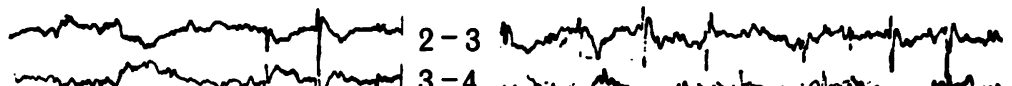

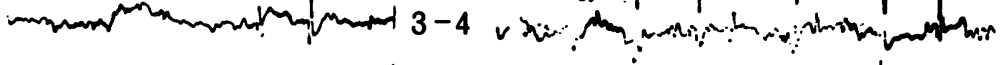

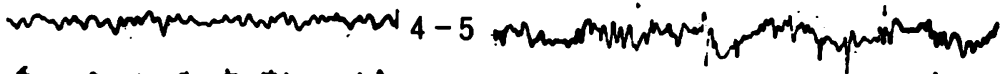

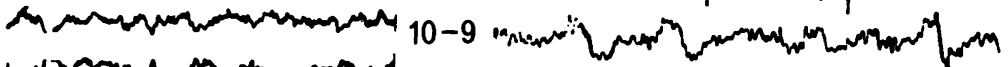

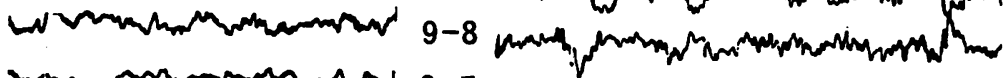

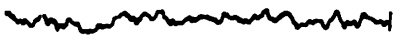

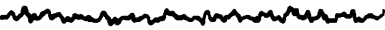

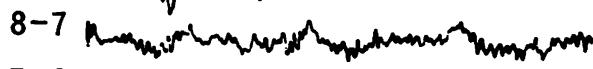
7-6

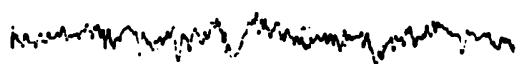

B Resting record After $50 \mathrm{mg}$ IV Methohexitone

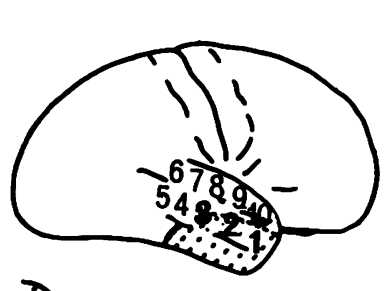

$\therefore$

Area excised

D.S.

$63610 / 10$ 2-8-68

FIG. 3. Patient 2. Showing the use of repeated injection of methohexitone. Recordings from two anteroposterior chains of electrodes. (A) Before excision. This shows the facilitation of spikes after intravenous methohexitone. (B) After partial excision of the anterior part of the middle and inferior temporal lobe gyri. Electrodes 1 and 2 are over the excised area. Spikes are increased again after methohexitone (C) Extension of the excision posteriorly to Labbe's vein. Electrodes 1,2 , and 3 are over the excised area. Intravenous methohexitone no longer facilitates the appearance of spikes. The increase of slow wave activity is usually seen after operation. 
thiopentone was used, where it was not so easy to contribute additional useful information to the surgeon.

\section{DISCUSSION}

In the patients studied, methohexitone quickly produced useful information in the ECoG, whereas thiopentone added very little to the information which had already been obtained either from the pre-operative EEGs or the ECoG recorded during inhalation anaesthesia only. The cases are too few and varied for any conclusions to be made with regard to the possibility that the underlying pathology might be responsible for these differing drug effects.

It might be argued that the dosages of thiopentone were not sufficient, but in all cases the dose was within the commonly regarded safe anaesthetic range, and was sufficient to induce fast activity in all the cases studied. The surgeon sometimes requires the patient's co-operation during the procedure and it is of obvious advantage to have a rapidly metabolized drug without cumulative effects. In this respect, methohexitone is clearly more useful than thiopentone. In addition, methohexitone in the cases presented appeared to facilitate relevant spike discharges, sometimes with small doses, and in one patient (case 1), did so when thiopentone failed.

It may be that this facilitatory property of methohexitone is related to the difference in chemical structure from that of thiopentone. Convulsant properties to such a degree as to make its anaesthetic use inconvenient have been found in the racemic form of methohexitone (Redish, Vore, Chernish, and Gruber, 1958). Certain other barbiturate derivatives have long been known to have convulsant properties (Dox and Hjort, 1927; Swanson, 1933; Knoefel, 1936; Bennett, 1960). These convulsant and hitherto detrimental side-effects (Galley, 1963) may form the basis of a new synthesis. It is to be hoped that it might be possible, by a further slight modification of the chemical configuration of methohexitone, to produce a compound with the same or even greater
EEG facilitating properties and with minimal narcotic effect.

\section{SUMMARY}

The ECoGs of 10 patients undergoing surgery for intractable epilepsy have been studied, to compare $\stackrel{\bigcirc}{-}$ the relative merits of thiopentone and methohexitone in facilitating abnormal spike discharges. Using. similar doses it was found that methohexitone was $\vec{\nexists}$ the more effective drug. Basic structural differences $\stackrel{5}{?}$ in methohexitone may be responsible for this effect and may provide the basis for subsequent syntheses.

We should like to thank Professor V. Logue for allowing us access to his patients.

\section{REFERENCES}

Bennett, I. F. (1960). Stimulatory barbiturates in psychiatry: Compound 31777. Dis. nerv. Syst., 21, 405-409.

Dundee, J. W., and Moore, J. (1961). Thiopentone and methohexital A comparison as main anaesthetic agents for a standard? operation. Anaesthesia, 16, 50-60.

Dox, A. W., and Hjort, A. M. (1927). The relative physiological. properties of certain trialkyl and dialkyl barbituric acids. J. Pharmacol. exp. Ther., 31, 455-472.

Fenton, G. W., and Scotton, L. (1967). The use of methohexitone 9 sleep electroencephalography. Electroenceph. clin. Neu䒬physiol., 23, 273-276.

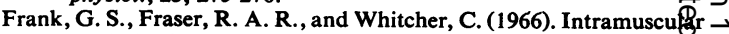
methohexital for rapid induction of short duration sleep iq $T$ the EEG laboratory: A study of forty-four hyperkinetic (D children. Ibid., 21, 76-78.

Galley, A. H. (1963). Methohexitone. Proc. roy. Soc. Med. (Section 8 f Anaesthetics), 56, 377-378.

Goldie, L., Fried, Y., Gould, T., and Pedersen, T. M. (1968). Elect encephalographs in the subnormal and the mentally ill chif. $\overrightarrow{0}$ Anaesthesia, 23, 364-371.

Knoefel, P. K. (1936). The action of a convulsant barbiturate. $J$. Pharmacol. exp. Ther., 57, 130.

Pampiglione, G. (1965). Very short acting barbiturate (Methohexital) in the detection of cortical lesions. Electroenceph. clin. Neurophysiol., 19, 314.

Redish, C. H., Vore, R. E., Chernish, S. M., and Gruber, C. M., Jr. $\overline{\bar{O}}$ (1958). A comparison of thiopental sodium, methitural sodium and methohexital sodium in oral surgery patients. Oral $\overparen{D}$ Surgery, 11, 603-616.

Riffin, I. M. (1960). An appraisal of new induction agents. J. med. Soc. N.J., 57, 15-19.

Swanson, E. E. (1933). Relationship between pharmacological action and chemical structure of barbituric acid derivatives. Proc. Soc. exp. Biol. (N.Y.), 31, 961-963.

Wyant, G. M., and Chang, C. A. (1959). Sodium methohexital: A clinical study. Canad. Anaesth. Soc. J., 6, 40-50. 